\title{
Introduction
}

\section{Toward a Feminist Constitutional Agenda}

\author{
Beverley Baines and Ruth Rubio-Marin
}

Women around the world increasingly resort to constitutional litigation to resolve controversies involving gender issues. This litigation has involved claims for political participation, freedom from discrimination and violence, sexual and reproductive rights, employment and civic rights, matrimonial and familial autonomy, as well as other social and economic rights. For the most part, constitutional law scholars have analyzed this jurisprudence doctrinally, confining their research mainly to individual flashpoint issues such as abortion or affirmative action. Such studies are usually framed by national boundaries; and, when comparative, their reach is often limited to a small number of countries sharing the same legal tradition. This explains the need for a feminist analysis of constitutional jurisprudence in which gender becomes the focal point and for a broader comparative constitutional law approach that encompasses both of the world's major legal traditions. Those are the focal points of this book.

Not long ago a feminist constitutional law scholar asked: "Can consti-

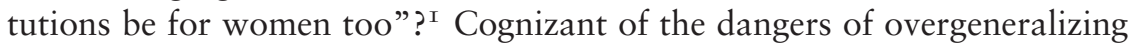
about women's experiences and concerns, she was cautious about responding affirmatively. Nevertheless, her message was clear. Although women may be un-, or under-, represented among the ranks of those who draft domestic constitutions, we are not entirely without constitutional agency. Whether constitutional language adverts or not to women, we still advance claims for constitutional rights. And, despite legal theory's conventional assumptions about defining constitutionalism as "the relationship among a constitution's authority, its identity, and possible methodologies of interpretation,"2

I Donna Greschner, "Can Constitutions Be for Women Too?," in Dawn Currie and B. MacLean, eds., The Administration of Justice (Saskatoon: University of Saskatchewan Social Research Unit, I986) 20.

${ }^{2}$ Larry Alexander, ed., Constitutionalism: Philosophical Foundations (Cambridge: Cambridge University Press, I998) I. 
feminist theorists have not hesitated to conceptualize it more contextually, as illustrated by the feminist philosopher who concluded "the constitution we have depends upon the constitution we make and do and are." 3 Thus women activists, lawyers, judges, and scholars appear to agree that what is at stake no longer is whether constitutions can be for women but, rather, when and how to ensure that they recognize and promote women's rights.

The "when" question is easy to answer. Now. It is timely to assert, litigate, protect, and promote the constitutional rights of women because of the confluence of two twentieth-century developments. One is scholarly and the other juridical. In the first place, feminist scholarship has begun to embrace the study of legal phenomena. Of course, analyzing law from the perspective of gender is by no means new. In the eighteenth century, Mary Wollstonecraft issued her Vindication of the Rights of Women, a publication that clearly entailed commentary on legal rules that impacted on women's lives. ${ }^{4}$ By the closing decades of the twentieth century, a number of scholars from various countries had published treatises on feminist legal theory, including therein works by the Norwegian scholar Tove Stang Dahl, British scholars such as Katherine O'Donovan and Carol Smart, the American scholar Catharine MacKinnon, and the Australian scholar Carole Pateman. ${ }^{5}$ Moreover, some contemporary feminist legal scholarship is comparatively but not consistently constitutionally oriented. ${ }^{6}$ The burgeoning literature on comparative constitutional law covers a wide range of topics, such as constitutionalism, rights, judicial review, federalism, governance, and economic development, while being virtually devoid of research that pertains to women's rights. In other words, there is a huge gap - a gender gap - in contemporary comparative constitutional analysis. ${ }^{7}$ The same cannot be said

3 Hanna Fenichel Pitkin, “The Idea of a Constitution” (I987) 37 J. Legal Educ. I67 at I68, continuing: "Except insofar as we do, what we think we have is powerless and will soon disappear. Except insofar as, in doing, we respect what we are - both our actuality and the genuine potential within us - our doing will be a disaster" (emphasis in original).

4 Mary Wollstonecraft, A Vindication of the Rights of Women, with Strictures on Political and Moral Subjects (London: John Johnson, I794).

5 Tove Stang Dahl, Women's Law: An Introduction to Feminist Jurisprudence (Oslo: Norwegian University Press, I987); Katherine O’Donovan, Sexual Divisions in Law (London: Weidenfeld and Nicholson, I985); Carol Smart, Feminism and the Power of Law (London: Routledge, I989); Catharine A. MacKinnon, Feminism Unmodified: Discourses on Life and Law (Cambridge, MA: Harvard University Press, I987); Carole Pateman, The Sexual Contract (Stanford: Stanford University Press, I988).

${ }^{6}$ Susan Bazilli, ed., Putting Women on the Agenda (Johannesburg: Ravan Press, I99I); Fiona Beveridge, Sue Nott and Kylie Stephen, eds., Making Women Count: Integrating Gender into Law and Policy-making (Aldershot: Ashgate Publishing Ltd., 2000).

7 A striking exception is the recent publication of Fiona Beveridge, Sue Nott and Kylie Stephen, eds., Making Women Count: Integrating Gender into Law and Policy-making (Aldershot: Ashgate Publishing Ltd., 2000). 
of comparative law scholarship in general. ${ }^{8}$ Nor does it extend to the study of historically disadvantaged groups other than women. Recently, for instance, comparative constitutional law scholars not only examined contemporary ethnic group conflicts ${ }^{9}$ but also studied the legal claims of religious communities. ${ }^{\text {IO }}$

In the second place, and coincidentally with this spate of feminist legal theorizing, have appeared constitutional doctrines that impact or have the potential to impact on women's issues. The same was not true for women who entered the twentieth century. The constitutional rights of women received little or no juridical recognition until well into the twentieth century. Moreover, this holds true irrespective of whether a country is relatively new to the world's stage or whether its roots go back for centuries. It should come as no surprise, therefore, that much still remains to be done in the twenty-first century to promote the process of "constituting" (or recognizing, sustaining and promoting) women's rights.

This brings us to the "how" question, which is more a challenge than a question. Writ large, the immediate question is how to use constitution making processes and, more than anything, the existing constitutional judicial processes to achieve gender equality for women. The challenge is complex because feminists and judges emphasize different material facts, rely on different terminology, reason quite distinctively, and do not necessarily share the same goals when they examine the issue of gender equality. Most feminists believe gender equality will not be achieved until the subordination of women is overcome. In contrast, some jurists deny that women's subordination is real, ${ }^{\mathrm{II}}$ whereas others question the value of relying on constitutional strategies for redress. ${ }^{\mathrm{I} 2}$ To give yet a further example, although legal reasoning

8 See, for all, V. Jackson and M. Tushnet, Comparative Constitutional Law, University Casebook Series (New York, New York Foundation Press, I 999); and N. Dorsen, M. Rosenfeld, A. Sajó and S. Baer, Comparative Constitutionalism: Cases and Materials, American Casebook Series (St. Paul, MN: Thomson/West, 2003).

9 E.g., Yash Ghai, ed., Autonomy and Ethnicity: Negotiating Competing Claims in Multi-ethnic States (Cambridge: Cambridge University Press, 2000).

Io Peter W. Edge and Graham Harvey, eds., Law and Religion in Contemporary Society: Communities, Individualism, and the State (Burlington, VI: Ashgate Publishing Co., 2000).

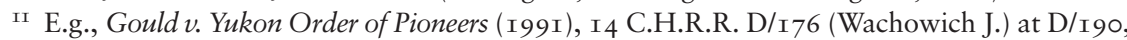
discussing why the sex equality provision in the Canadian Constitution might not be "available to combat allegedly discriminatory behaviour against all women. In my view women, as a group, are not what is commonly understood to be a 'minority' in Canadian society. The intervener stated that a recent Yukon census showed that 53.I percent of the population was male, while 46.9 percent was female. Whether this constitutes a minority that can be discriminated against is in doubt."

${ }^{12}$ E.g., Robert H. Bork, The Tempting of America: The Political Seduction of the Law (New York: Simon \& Schuster Inc., I990) 330: "I had taken the position that, except for this rational basis test, the equal protection clause [in the American Constitution] should be restricted to race and ethnicity.... There is unlikely to be much work for the equal protection clause to do with respect to governmental distinctions between the sexes because legislators are hardly 
is invariably deductive, feminists are as likely, if not more likely, to reason inductively. Under these circumstances, common sense suggests developing the relationship between feminist theorizing and constitutional reasoning in several stages, rather than thrusting them together and holding our breath as we wait to see if the marriage will endure.

More specifically, we advocate developing a feminist constitutional agenda, which like any good ordering device should admit of some degree of flexibility. At a minimum, however, this feminist constitutional agenda should address the position of women with respect to: (i) constitutional agency; (ii) constitutional rights; (iii) constitutionally structured diversity; (iv) constitutional equality; and give special attention to (v) women's reproductive rights and sexual autonomy; (vi) women's rights within the family; (vii) women's socioeconomic development and democratic rights.

This listing is lengthy. However, it would be even longer were it to contain all the context- and fact-driven issues that could constitute an agenda structured solely along feminist lines. Indeed, its length offers no consolation to women who are lesbian, bisexual, or transgendered, women with disabilities, and/or elder women who do not see their rights reflected on it. They will assume their claims lie buried within the listed categories. Moreover, this listing is also vulnerable to the criticism that some issues might overlap more than one theme. These shortcomings notwithstanding, the virtue of making our proposed feminist constitutional agenda as extensive as it is, lies in the fact that it is significantly more detailed than most of the agendas that are designed from a purportedly "gender neutral" constitutional law perspective. Such scholarship tends to address issues as if they pertain either to federalism and separation of powers, or to constitutional rights. Typically, the latter research will be further bifurcated into studies focusing on one of two main strategies for dealing with rights conflicts. The more popular strategy is autonomy, which encompasses claims that range from privacy claims to the collective claim of self-determination. ${ }^{13}$ Thus, when perceived in terms of self-determination, autonomy is the rallying cry of many indigenous, racial, ethnic, and linguistic groups. On occasion, most of these rightsseeking groups also turn to the other major strategy for managing rights conflicts, which is equality. Although these three major constitutional law categories - federalism, autonomy, and equality - might capture women's claims, they also might distort and/or impoverish them, viz. should claims of democratic underrepresentation be subsumed under autonomy or equality, or are they sui generis? Also, with only three categories at their disposal,

likely to impose invidious discriminations upon a group that comprises a slight majority of the electorate."

I3 Yash Ghai, ed., Autonomy and Ethnicity: Negotiating Competing Claims in Multi-ethnic States (Cambridge: Cambridge University Press, 2000) at I: "One of the most sought after, and resisted, devices for conflict management is autonomy." 
scholars might be tempted to portray the relationships among them as adversarial, viz. treating pornography as a contest between the pornographers' autonomy and the equality rights of women and girls, which would neglect entirely the entitlement of the latter to self-determination or autonomy.

Thus, we propose to design a feminist constitutional agenda as a middle course between the extensive and reality-driven delineation of issues that feminist scholars advance and the more rigidly bounded, often threefold, doctrinal categorization found in constitutional law scholarship. The main purpose of this introduction is to raise some of the major questions that should be addressed under each of the headings described in the hope that, when approaching the different national experiences that are described in this book, the reader will be able to identify the span of possible answers and assess their practical impact. The reader will realize that the themes are in fact drawn from the national chapters that follow. Not every theme is found in every chapter, and some chapters may contain other themes that have not been explicitly added to this agenda. Knowing that some themes overlap, and that some themes should be but are not self-evident in our listing, we invite feminist constitutional law scholars to continue what we have begun by de- and reconstructing our agenda themes as part of our larger project of encouraging judicial recognition of the constitutional structures and rights necessary to overcome the subordination of women. Our primary goal is, in short, to identify, sustain and promote the constitutional norms and strategies that will achieve gender equality for women. To this end, we invite feminist, legal, and other interested scholars to think about constitutions in a gendered way.

The contributors to this volume have done precisely that. This book is designed to explore these themes as they are manifested in the constitutions and constitutional jurisprudence issued by the national courts in twelve countries: Australia, Canada, Colombia, Costa Rica, France, Germany, India, Israel, South Africa, Spain, Turkey, and the United States. These countries span several continents, cover diverse legal traditions and collectively represent constitutional regimes that were adopted over a period of almost three centuries. Although the overall scope of this coverage matters, there was no magic in the number of countries chosen. Rather inclusion was based on balancing a number of structural features, including representation of the major legal traditions (civil law and common law), governance structures (monarchy and republic), legislative regimes (parliamentary and presidential), adjudicative mechanisms (constitutional courts and general courts), and jurisdictional structures (federal unions and unitary states). Other factors that distinguish these countries include their racial, religious, linguistic, and cultural demographics. As well, these particular countries derive their constitutional rights from a wide range of sources including entrenched bills of rights, unwritten principles, ordinary statutes, and international human rights treaties. Arguably the more extensive the structural, social, and legal 
diversity of these countries, the more compelling the similarities, if any, that crystallize from analyzing their jurisprudence.

Even though each national contribution should be perceived as part of the larger enterprise of conceptualizing the themes on a feminist constitutional agenda, each also stands alone as a chapter describing that country's constitutional jurisprudence as it pertains to women. Crucial to the selection process was, therefore, the willingness of country contributors to examine the role of women as constitutional agents, analyzing their engagement in constitutional litigation and adjudication, as well as in constitution making and amending processes. We also encouraged contributors to highlight the most progressive element(s) of the constitutions and of the constitutional jurisprudence that national courts have adjudicated on behalf of women's claims in the hope of encouraging strategical extrapolation.

More specifically, we asked them to discuss who makes constitutional claims, what kinds of rights inform these claims, how these claims have evolved over time, what kinds of arguments work in defense of these claims, and how these claims relate to the larger social, economic and political issues that contemporary countries are facing. We urged them to provide a comprehensive reference to the most important case law and relevant constitutional provisions, as well as a brief bibliography that could serve as a guide for further research. The contributors, all of whom are academics and/or advocates on behalf of women's rights, remained true to their training as lawyers, responding both critically and constructively. Their chapters illuminate their constructive critiques partly by addressing selected common themes and partly by developing the most original themes that each national experience offers in terms of constitutional gender jurisprudence.

Three caveats should be borne in mind. First, our feminist constitutional agenda is just that, an agenda and not a recipe. We propose themes to open this field for further examination and not to foreclose alternative approaches. While trying to identify some of the factors that are to be taken into account in a gender-sensitive constitutional analysis and inviting the contributors to reflect upon them in the context of their national experiences, aware of the richness and intricacies of each constitutional system, we have purposefully avoided drawing direct causal-effect conclusions that might have been rightfully criticized as oversimplifications. Second, although we asked the country contributors to emphasize constitutional doctrine and jurisprudence, we do not intend to suggest that constitutional progress is synonymous with social progress. In some instances, law may be more often an aspiration than a set of binding norms; judiciary systems may be more or less reliable when it comes to applying doctrine; and in some countries the doctrines relevant to women's rights are too new and/or fragmentary to be coherently systematized. Third, even as a study of this kind invites extrapolation from one country to another, we recognize the need for carefully keeping in mind the deep differences that exist between and among countries not only culturally 
but also in terms of their legal traditions. Legal traditions vary according to the significance they attach to constitutional law, to competing sources of law including religious authorities, indigenous traditions, and international law, as well as to judicial review.

\section{WOMEN AND CONSTITUTIONAL AGENCY}

For centuries, states openly barred women from participating in civic life, whether as voters or legislators, lawyers or jurists. Men also monopolized constitutional activities. Not surprisingly, women's initial forays into the realm of constitution-making focused primarily on voting, although their strategies differed. On the one hand, white women in two Australian colonies were not only the first to receive the franchise, but also in I90I they became the first women to vote on a constitution. On the other hand, following decades of lobbying, in I920 Americans became the first to secure a constitutional amendment guaranteeing women the right to vote. Although these initial strategies were important, however, it is curious that they did not lead to any further formal constitutional changes for women in either country.

The embrace of formal equality and the explicit commitment to sex equality only became a general trend in postwar constitutionalism. Women's role in promoting those provisions is unclear. Given pervasive underrepresentation in legislative and constituent assemblies, it would not be surprising to find that their activities were limited. However, during the I980s and I990s, women began to engage actively in processes of general constitutional renewal. For instance, not only did Canadian women lobby to strengthen the sex equality guarantees newly entrenched in the Charter of Rights and Freedoms (I982), but also women in Colombia successfully advocated for gender equality and gender-related provisions in their new Constitution (I99I), and South African women actively participated in the process of drafting their new Constitution (I996). Finally, by procuring an amendment (I999) that requires gender parity in selected electoral contests, French feminists may have portended a new era, one in which women could seek specific genderrelated constitutional amendments as needed rather than only during times of general constitutional change.

The foregoing suggests women who are active in feminist movements have begun to identify constitutions and constitutional change as relevant to our lives. With more comparative analysis, we may better understand when to initiate constitutional change on behalf of women, whether to intervene in changes already underway, what strategies are appropriate to each context, and how best to connect the international with the national fora, how to engage other women in these processes, and what results are most likely to undermine the prevailing patterns of political, social, and economic subordination of women. Thus, politically speaking, there is much to learn from the 
roles women have already played in the constitution making and amending processes and initiatives.

The process of litigation offers women ways of developing and changing the meaning of constitutional norms. The country chapters in this volume exemplify this process at work, tantalizing us with questions of measurement (how active have women been in litigating?) and quality (what claims do women litigate and with what consequences?). More specifically with respect to the level of women's litigious activity, what institutional mechanisms are most likely to overcome conventional barriers to accessibility by helping women as a group to avail themselves of constitutional tools? The possibilities include the design of standing rules and class action rules, as well as the provision of funding for litigation, of officials who institute actions such as ombudpersons, or of organizations that specifically protect women's rights in constitutional litigation such as the Women's Legal Education and Action Fund (LEAF) in Canada or the more controversial Commission for Gender Equality in South Africa.

Understanding women's constitutional agency requires an understanding of the types of claims that women bring, and the constitutional strategies on which they rely. There is no question that, although the strongest emphasis has been on equality provisions, gender-related litigation has proceeded under most of the other rights-based provisions as well as under some federalism provisions. In this context, it is worth considering whether specific groups of women are more litigious than others and if so, how this impacts on the way in which doctrine is shaped. It also is interesting to observe to what extent men's agency has had an impact on women's. Moreover, gender-related doctrine may be affected in cases in which women are defendants or not even parties, as for example in most sexual assault prosecutions. Finally, any assessment of the quality of women's constitutional litigious agency would not be complete without an assessment of the difference, if any, that is made by having women on the final appellate courts that decide constitutional matters.

In sum, women's constitutional agency involves lobbying, legislating, litigating, and adjudicating. Although all of these roles are open to women, as the different chapters show, our entry is not commensurate with our numbers, suggesting invisible but real public constraints, perhaps not unlike the proverbial glass ceiling in the private workplace. Nor should women mistake bestowals of nice-sounding principles for the efforts of agency. As the Turkish experience shows, men can use women's equality for their own purpose. In other words, progress and agency need not go hand-in-hand.

\section{WOMEN AND CONSTITUTIONAL RIGHTS}

Constitutional rights provide women and other rights seekers with the tools to challenge state activity in the courts. They offer more protection than 
statutory and other nonconstitutional rights which may not constrain legislation. Also controversies involving statutory and other nonconstitutional rights are not necessarily resolved by courts; often they are designed to be heard at least initially, if not finally, by administrative tribunals or government officials.

Nevertheless, arguably there is one important respect in which statutory and other nonconstitutional rights might be perceived as offering better protection to rights seekers, especially rights seekers who are unaccustomed to the methodology of legal reasoning. Put simply, while constitutional provisions tend to have a greater visibility and seem to permeate more easily the general legal culture than statutory rights do, statutory rights are often detailed, making their meanings more transparent and accessible to rights seekers. In contrast, constitutional rights are usually expressed in terms of abstract generalities so that their meanings are dependent on the interpretations judges have ascribed to them. Thus, understanding constitutional rights involves understanding the claims litigants have raised and judges have adjudicated. In fact, this may make less relevant the varying degrees in which rights can be constitutionally framed, which, as the national cases addressed here show, range from extremely detailed formulations to very limited or even nonexistent.

In any event, the country chapters reveal that women's constitutional rights claims have encompassed a wide array of grounds. Some of these grounds have been unique to women from individual countries. For instance, women have constitutionally reacted against the desecration of sacred land in Australia, police failure to warn about a serial rapist in Canada, forcing contraceptives on female prisoners as a condition of conjugal visits in Colombia, gendered prayer rights in Israel, the restitution of conjugal rights in India, the order of family names in Germany, or male preference rules in the inheritance of nobility titles in Spain. But many other grounds have been raised more generally. For example, women have often used constitutional instruments to fight against pregnancy and employment discrimination, domestic violence, political underrepresentation, sexual harassment, military service discrimination, sex crimes and/or their accompanying procedures, or unfair marriage, divorce, and succession rules.

Given their breadth, it is striking that few if any of these grounds are expressly prohibited in contemporary constitutions. This lacuna forces women to figure out constitutional strategies to react against the liabilities involved, ground by ground, and country by country. Having to contend on a caseby-case basis for subsuming specific prohibitions within the more abstractly worded provisions found in most constitutions is resource intensive and energy depleting. Moreover, many women simply cannot afford to undertake such an approach. Thus, the insights of comparative analysis suggest feminist and other legal scholars should reassess the current practice of refracting constitutional rights through a myriad of grounds. The flexibility of expressing 
constitutional rights abstractly may or may not assist women. One of the dangers in silence is that it forces women to rely on the more generic equality provision, but doing so forces women to phrase their claims always in comparative terms. Because the parameters for the comparison are provided by men's experience, presumably, this strategy has inherent limitations.

However, constitutional rights are no panacea. Constitutional rights espouse, and are expected to espouse, the fundamental values of a nation and this has both good and bad consequences for women because courts are prepared not only to uphold but also to limit women's claims in the name of these fundamental values. For instance, as we will see, this has worked to women's disadvantage when restrictive abortion laws were challenged in countries where the courts responded by upholding restrictions, or even by strengthening them, in the name of the foetus and the value of life. In other words, the antithetical consequences that ensue when constitutional rights also serve as constitutional limits should be factored into any consideration of the feasibility of adopting more explicit or grounded expressions of women's constitutional rights. Also, freedom of speech has traditionally been asserted against attempts to limit the harm women suffer because of pornography.

No analysis of women's constitutional rights would be complete without referring to the sphere of application of constitutional rights. Some countries, virtually all of the common law countries analyzed here, restrict the application of women's challenges to state (or public) activity, whereas others, mostly of the civil law tradition, allow women to rely on constitutional rights to challenge injustice and discrimination in the private sector, including the family, schools, workplace, or the media. This distinction between countries that require state action and those recognizing the "horizontal" effect or Drittwirkung of constitutional rights is especially relevant to women. It evokes the public/private controversy that fuels much of feminist theory. Often the most serious forms of discrimination are those that women encounter in the private sphere. Nevertheless, those countries that strictly adhere to the constitutional state action doctrine often have general antidiscrimination legislation addressing systematically the various forms of discrimination that women encounter in civil society so that, in practical terms, the difference might not be so dramatic.

Finally, some consideration should be granted to constitutional hermeneutics as well. Have different methods of constitutional interpretation a gender impact? Time may make a difference here. Presumably, if the constitution is an old document written at a time when women's subordinate status was accepted as the natural order of things, and if the courts prefer an originalist or textual approach rather than a "living tree" or teleological approach, this may have a negative impact on women's constitutional position. Also, the different relevance constitutions attach to international human rights instruments and supranational law can have a clear impact on women's 
constitutional status. Here again, the evidence drawn from our chapters seems to suggest such relevance is accorded more significance in civil law than in common law countries and that in those constitutional regimes that have accorded a special place for international norms in the constitutional order, this has indeed made a significant impact on the gender sympathies of the constitutional bench. ${ }^{\text {I4 }}$ As we will see, some constitutions expressly incorporate international law as domestic law. Costa Rica even grants it superior legal force to that of the constitution. More common, however, is the recognition of the need to interpret constitutional rights in the light of relevant international or supranational law. CEDAW is, for instance, often invoked and European Law is sometimes very relevant to constitutional interpretation in EU Member States, like France, Germany, or Spain. How does this impact the constitutional status of women? When specific judicial bodies have the competence to interpret the international or supranational law at stake (such as the European Court of Human Rights or the European Court of Justice) and to bind national constitutional courts to receive such interpretations and to incorporate them to their own interpretation of the national constitutions, interesting questions arise concerning which becomes the final authority to which women can turn.

\section{WOMEN AND CONSTITUTIONALLY STRUCTURED DIVERSITY}

Although women have participated in revolutionary activities gender conflict has never caused a national revolution. Indeed, there is little evidence that gender conflict has influenced the design of the constitutional structures that promote national unity and postpone revolution. Instead, economic, cultural, and religious conflicts have dictated the choices of constitution makers in selecting their country's form of governance (whether monarchy or republic), territorial principle (whether federation or unitary state), and jurisdictional approach (whether to recognize customary or religious laws). Accordingly, feminist scholars are constrained to examining the impact on women of these various constitutional structures and the diversities that underlie them.

For instance, the choice between monarchical and republican forms of governance seems gendered because the vast majority of the world's monarchs have been and are men. Nevertheless, that is not always the case and also the rule of primogeniture, or male preference succession that prevails in many monarchies is indistinguishable from similar male preference leadership rules or choices to which various republics adhere. Seldom have

I4 On the topic, see R. Rubio-Marín and M. Morgan, "Constitutional Domestication of International Gender Norms: Categorizations, Illustrations, and Reflections from the Nearside of the Bridge," in K. Knopp, ed., Gender and Human Rights (Oxford: Oxford University Press) [2004]. 
republican leaders been female. In sum, the real question is what constitutional objective is served when male preference rules directly or indirectly structure institutions of governance, and will the gender neutrality of the most recently adopted constitutions make any difference?

When nations choose federation over unitary status as their territorial principle, usually it is for economic reasons, often attached to geographical considerations although sometimes ethnocultural conflict also plays a role, as happens in Canada or India. From the perspective of women, however, the major consequence of this choice is often to allocate "private" matters to the regional entities rather than to the national level. For instance, it is common to find that family law becomes a matter for regional concern, and frequently employment law follows suit. Criminal law is, in contrast, sometimes a national and sometimes primarily of regional concern. These and other territorial distributions of legislative power suggest the importance of examining their impact on women, particularly from the standpoint of feminist theorizing about the public/private split.

Without doubt the structural choice about which feminists have been most vocal is the decision to recognize customary or religious jurisdiction over certain relationships, often including those which are the most intimate and intense, such as marriage, divorce, custody, property, and succession. Nevertheless, feminist responses to these jurisdictional choices have not been monolithic; rather, they have been context specific. For instance, as we will see, many Australian and Canadian feminists have supported the recognition of legal rights for indigenous peoples, particularly the efforts indigenous women have made to identify and assert their customary rights. However, the recognition of personal religious laws in India, of religious laws in Israel, and of customary and religious laws in South Africa is more controversial. In these countries, feminists have not hesitated to identify some disadvantages women experience under these religious and customary jurisdictions, and to argue for the necessity of greater harmonization with women's constitutional rights. Finally, in a country such as Turkey, which has adopted a policy of secularism in spite of its overwhelmingly Muslim population, the ban on women wearing religious headscarves in universities has caused feminists to differ. Comparative constitutional analysis signals thus the necessity for examining the impact on women of governmental or judicial decisions to recognize or assimilate religious and/or customary laws.

\section{WOMEN AND CONSTITUTIONAL EQUALITY DOCTRINE}

Most constitutions, especially if they have been recently drafted, explicitly prohibit sex or gender discrimination, and/or guarantee equality rights to men and women or to male and female persons. Pragmatically speaking, the promise of these provisions is clear. Because the oppression of women remains a worldwide phenomenon despite some national variations, these 
provisions are available to support women's equality claims (in fact, many constitutions also explicitly approve of positive discrimination in cases where historic discrimination is being remedied). Although the equality provisions do not preclude men from claiming their protection, effectively they were drafted to protect women. The idea is so widely spread that even in countries without generic sex equality provisions in their constitutions such as Australia, Israel, or the United States, there is jurisprudence pertaining to women's constitutional right to equality. All are, in other words, past the moral and philosophic preliminaries of whether and why to identify women's equality as a constitutional matter. What remains are the more pragmatic issues of the what, when, and how of the constitutional adjudication of sex equality claims: What does sex equality mean? When can women claim infringement of their constitutional right to sex equality? How should courts remedy sex inequalities?

Quite independently, the contributors to this volume approach these questions from the same discursive starting point. They analyze the national constitutional jurisprudence as if sex equality had more than one meaning. Two doctrines prevail, although jurists do not always employ the same terminology as scholars. One is formal equality; the other, separate but equal. Both doctrines rely on the Aristotelian notions of treating alikes alike, and unalikes unalike. Accordingly both focus on identifying the relevant differences and similarities, whether biologically or socially determined, between men and women as groups. Where they differ is in their emancipatory strategies. Formal equality assumes the sex of a person reveals nothing about individual worth or autonomy; its main objective is to create a gender neutral legal order, which turns out to be one in which women are treated just like men. In contrast, its nomenclature suggests separate but equal doctrine emphasizes respect for and the value of women's differences, while promising to ensure they do not result in worse treatment.

Whatever the doctrine formally embraced, the same kinds of issues arise. Thus formal equality courts have struggled to accommodate pregnancy discrimination and affirmative action by treating them as limited exceptions, while separate but equal courts have found it difficult to distinguish legislative stereotyping or paternalism from the less debilitating manifestations of protective or symbolic legislation. Taken collectively, these doctrines portray sex as an abstract conceptual category that is vulnerable to the excesses of judicial discretion; and more important, both focus on open and direct differentiation between the sexes, thereby failing to identify discrimination that is embedded in gender neutral or gender specific legislation. Each of these critiques is exemplified, where pertinent, in the country chapters.

However, the country contributors also constructively advert to the existence of a third sex equality doctrine. Most contributors use the term "substantive equality" to denote this third doctrine. Unlike the other two equality doctrines, it is not obsessed with identifying similarities and differences 
between men and women (to build upon them the "similarly situated test"), nor with trying to classify them as biological or socially constructed. Substantive equality tries to identify patterns of oppression and subordination of women as a group by men as a group on the understanding that most sex discrimination originates with the long history of women's inequality in almost every area of life rather than inhering in sex as a conceptual category. Ultimately, therefore, the goal of substantive equality is to transform social patterns of discrimination, partly by uncovering the inequalities embedded in gender neutral laws and partly by challenging schemes that differentiate women by offering us only paternalistic benefits. Unfortunately, even under this doctrine there is hardly any way of getting around the objection that some of the "benefits" or "advantages" that the doctrine tries to extend to women rely on traditionally male definitions of the good life. At the same time, some of the goods at stake are so basic (think of life, physical integrity, shelter, and food) that they can be assumed to be a part of anybody's conception of the good life.

Although some national courts have never adverted to substantive equality, it is possible that some of these national differences are semantic. In other words, there may be other ways of referring to the third meaning of equality in constitutional litigation. Be that as it may, the delineation of these three doctrines not only has timing and remedial consequences but also poses issues about limits. What follows is, therefore, a brief delineation of some of the questions raised by adopting the different doctrines of equality.

With respect to timing, the country jurisprudence confirms a pattern in which reliance on the separate but equal and formal equality doctrines often precedes the invocation of substantive equality doctrine. Can we indeed identify general trends in this regard? Does this mean that the earlier doctrines have historically limited functions? If so, can these limitations be attributed mainly to their focus, which is on direct or intentional discrimination rather than on discrimination that is indirect or effects based? What happens when substantive equality appears in the national jurisprudence? Can the three doctrines coexist? What are the tensions that come about? What happens if the tensions are not faced or resolved?

What remedial implications attach to the different equality doctrines? Remedying discrimination and inequality is undoubtedly complex. In exercising judicial review, national courts may choose among various options including: striking down legislation and denying the benefits or privileges to everyone; expanding legislative benefits or privileges to the excluded group; or denouncing the discriminatory legislation while deferring to the legislature to make changes. Comparative constitutional analysis permits us not only to ask about the remedial strategies that national courts have adopted in cases where women (or men) allege sex discrimination, but also to compare these remedial responses cross-nationally. Within the parameters of substantive equality jurisprudence alone, this approach encourages us to ask: Does 
gender matter? Does context matter? Does the nature or scope of the benefits or privileges matter?

What does the national jurisprudence reveal about the limits of the different equality doctrines? As we will see, the country chapters suggest that three contexts are most apposite to examining these limits: affirmative action, protective legislation, and men's discrimination. With respect to affirmative action, what explains different national responses to it, in itself and as applied to specific realms? What national standards control the validity of affirmative action? What limits, if any, are imposed to exclude measures that benefit individual women while negatively impacting on women as a group because they are paternalistic and have stigmatizing effects or because they sanction sexist stereotypes? Are affirmative action measures accepted when, whatever their long term effects, they compensate the present generation of women for actual disadvantages they currently face? How is the necessity for affirmative action justified - by the rhetoric of equal opportunity or that of equality of results? What is the connection between substantive equality and affirmative action? Does a commitment to substantive equality, as opposed to formal equality, mean conceptualizing affirmative action more as a fulfillment of equality rather than as an exception to it?

Protective legislation has become a pariah in countries that subscribe only to formal equality. However, this does not obviate its existence; nor does it necessarily evoke the same constraints in countries imbued with the substantive equality approach. Moreover, protective legislation poses a particularly poignant problem for women in countries which are in transition to a new constitutional order. Although we rely on substantive equality doctrine to identify and abolish paternalistic and stigmatizing legislation, nevertheless some laws provide women with benefits or privileges that are hard to relinquish. Because this issue is most sensitive in countries in transition from regimes that were oppressive toward women, it is appropriate to ask whether the courts have made allowances for relevant exceptions. For instance, who should pay the costs when the generation claiming the retention of those double-edged benefits is the generation caught in the middle of a democratic transition? Might the older generation not be doubly punished, first in living under an oppressive regime and then by the subsequent emancipatory laws that deprive them of the compensation and protection that they had legitimately come to expect? What role does and should the doctrine of substantive equality play to resolve these questions?

How are the different equality doctrines equipped to remedy men's discrimination? How often and in what contexts do men raise constitutional claims based on gender discrimination? Related to that, how are men helping to shape the meaning of sex discrimination? The different doctrines provide different answers. For instance, formal equality identifies any differential treatment that benefits women as discriminatory against men, whereas substantive equality might characterize the identical situation as 
nondiscriminatory if its effect were to remedy disadvantages that women face. Or, again, measures that privilege women and not men may meet the separate but equal test while failing the substantive test for women's equality because they provide women with paternalistic benefits. Irrespective of whether the suspect measures are scrutinized to ensure they do not backfire against women, the question remains as to whether men should avail themselves of equality doctrine to access those benefits. Are there genuine cases of male sex discrimination wherein men are denied equal material or nonmaterial advantages because of gender roles that disadvantage them? What have the various national practices been? Has formal equality served this purpose, as for example when men have claimed their right to experience the benefits and burdens of paternity as fully as women experience the benefits and burdens of maternity? Have the courts made relevant distinctions between the different claims presented by men?

Finally, irrespective of which doctrine judges apply, they must relate it to the prevailing concept of discrimination and, on occasion, to other constitutional rights and freedoms. These relationships give rise to various issues, as the following questions illustrate. Must discrimination affect all women equally in order to qualify as such and, if so, with what consequences? Do national courts recognize intersectional discrimination, that is discrimination based on more than one prohibited ground, or must women choose only one ground (think of sex vs. aboriginal status, race, caste, or religious identity)? What are the consequences for sex equality of relying on a concept of discrimination that was shaped on grounds other than sex? Do the traditional liberal rights and freedoms - such as freedom of expression, freedom of religion, privacy, due process, the right to a fair trial, and other procedural guarantees in criminal law - limit the constitutional right to sex equality? Are these tensions recognized? How are they resolved?

\section{CONSTITUTIONALIZING WOMEN'S REPRODUCTIVE RIGHTS AND SEXUAL AUTONOMY}

Very few constitutions advert to reproductive rights even though they are vital to women as individuals and as a group. However, in most countries with constitutional justice there are a number of cases involving reproductive issues that are not specifically denominated, such as abortion, in vitro fertilization, contraception, and sterilization. Because these processes were (and some still are) criminalized or otherwise regulated, litigants have resorted to more generalized rights to challenge their constitutionality. Comparative analysis of this jurisprudence will reveal whether distortions have resulted from reclassifying these reproductive claims.

The abortion jurisprudence is particularly apposite to illustrate the complexities induced by having to argue reproductive rights claims from a default position. Many countries have criminalized abortion subject to one or more 
exceptions (e.g. therapeutic, rape survivors, medicalized procedures). In the absence of abortion rights, litigants are forced to turn to a broad and diverse range of rights to sustain women's entitlement to control their own bodies, including security of the person, liberty, equality, privacy, free development of one's personality, physical integrity, human dignity, physical and moral integrity, and freedom of thought and belief. Comparative constitutional law scholars should examine how these alternative rights were conceptualized, whether they differ, where they overlap, how easy or difficult they made it to argue abortion claims, what distortions they posed for such arguments, and what consequences they had for women's reproductive rights.

Irrespective of which rights were argued on behalf of women, however, invariably a claim is made, usually by the state, for constitutional protection of the right to life of the fetus. Indeed, this claim can be and has been advanced in IVF cases. Such fetal right to life claims raise four issues. First, do all constitutions explicitly protect the right to life and when they do, how is this right conceptualized? Second, are fetal claims always subsumed under this right and when they are, how is this argument sustained? Third, what is the relevance of arguing about fetal rights in cases where women's reproductive rights claims are the basis for challenging the constitutionality of a law? That is, do judges rule that women have reproductive rights before deciding whether these rights are trumped by the right to life, or do they ignore reproductive rights issues and focus only on fetal claims? Fourth, do judicial resolutions of the foregoing issues - interpretation of the right to life, analysis of fetal claims and approaches to women's reproductive rights - correlate with the outcomes in the cases, given they range from decriminalization albeit subject to regulation in some countries to continuing criminalization in the others?

Future comparative law studies may explore the constitutionality of regulating specific features of the abortion process, including counselling, funding, parental or spousal notification, and sex selection, as well as considering whether states might have a duty to provide abortion facilities. Moreover, the reproductive jurisprudence involving contraception, sterilization, and IVF merits examination partly for intrinsic reasons and partly because it may be instructive for abortion claims. For example, the constitutionality of regulating access to IVF as in Costa Rica, or of denying it to lesbians as in Australia or divorcees as in Israel, not only impacts on women's autonomy as a group but also has consequences for our equality rights since much of this litigation was conducted under this constitutional rubric. As many of our country contributors recognize, it is increasingly important to acknowledge that equality analysis also is relevant to abortion issues. Thus comparative law scholars should analyze equality as well as autonomy and privacy when they examine the constitutional mandates that are most likely to inform women's reproductive rights jurisprudence. 
Abortion is not the only issue in which constitutions have been more commonly used to obstruct than to facilitate women's emancipation. Sexual offences, too, represent a site of controversy about which comparative constitutional law scholars would be hard pressed to deny that the entrenchment of constitutional rights has detrimentally affected women. Whether criminalized or otherwise regulated, sexual offences - including rape, prostitution, pornography, adultery, honor killings, hate speech, sexist speech, and sexual harassment - have created a veritable industry of constitutional litigation for the criminal defense bar. Relying on traditional legal rights such as the presumption of innocence, the right to a fair trial, and the right not to be subject to cruel and unusual punishment, as well as on freedom of expression, equality rights, and the right to life, liberty, and security of the person, male defendants have not hesitated to challenge the constitutionality of various sexual offences and the evidentiary or procedural rules pertaining to them. To illustrate, not only have men challenged the criminalization of rape in countries such as India and statutory rape in countries such as Canada and the United States, they also have invoked constitutional rights to argue for liberal access to the sexual history of the rape survivor and to her therapeutic counseling records in Canada, as well as to justify more lenient penalties for marital rape in Colombia.

As the victim-survivors, women are all but invisible, enduring these constitutional challenges without having a litigation status from which to respond. Despite this disempowerment, women have demanded that we be accorded constitutional protection for our sexual autonomy. Sometimes victims' lawyers make these assertions in court; sometimes prosecutors can be encouraged to voice them, albeit usually with the objective of protecting the state's interest in the impugned legislation. Either way, the discourse has been framed in terms of various rights including equality, life with dignity, freedom of expression, and honor. Not only should this jurisprudence illuminate how national courts address tensions among constitutional rights, but also it should yield a picture of which rights they favor. In sum, when women claim the right to constitutional protection of sexual autonomy, can national courts hear our voices?

\section{WOMEN'S RIGHTS AND THE CONSTITUTIONAL DEFINITION OF THE FAMILY}

The family is often the object of explicit constitutional protection. However, as the following chapters show, the presence of constitutional provisions referring to the family does not determine whether countries have constitutional jurisprudence pertaining to it. Rather, such jurisprudence pervades all of the country chapters. In other words, the family has acquired a constitutional veneer, whether by political and/or judicial decree. Thus it is important to examine how this constitutionalization of the family has affected women's 
rights. The idea that constitutions should (implying can) stay out of the home is indeed a myth.

From a comparative law perspective such studies raise a number of issues. Writ large, we need to understand how constitutions and constitutional doctrines shape and are shaped by national conceptions of the family. For instance, is curial discourse restricted to recognizing only formally married, sequentially monogamous, heterosexual couples or have the national courts been asked to accord matrimonial status or at least some family benefits (e.g., survivors' pensions, protection of children born out of wedlock, succession, and property rights) to common law or de facto families, to single-parent families, to polygamous unions, or to gay men and lesbians? Can constitutions really be neutral about family arrangements? In rendering these decisions, moreover, have courts acknowledged their specific impact on women's well-being?

More specifically, how do judges decide cases in which they are asked to treat wives or mothers differently from husbands or fathers? Collectively speaking, there are many such cases and they cover a wide range of subject matters, including family or children's surnames, income tax deductions and attributions, disposition of matrimonial property, survivors' pensions, inheritance, divorce, alimony, custody and support of children, restoration of conjugal rights, adultery, adoption, and domestic violence. This jurisprudence should enable scholars to identify the constitutional justifications that convince national courts to sanction the division of family roles on the basis of gender.

There also are other issues that merit attention. For example, when constitutions make families the object of collective rights protection (typically, by sanctioning the right to family privacy), does that impair the rights of women as individuals? How do courts balance the interests of children versus those of the father and/or the mother? Does the embrace of the doctrine of the horizontal effects of constitutional rights open a path for fighting against unfairness and oppression inside of the home? Is domestic violence a constitutional offense? How, if at all, do constitutions conceptualize women's domestic labor? What is the constitutional debate surrounding the impact of personal, religious, and customary family law on women's rights? What role, if any, does federalism play in the constitutionalization of the family? Ultimately, feminist scholars should also ask: Does constitutional doctrine sustain the fiction of the split between the private and public?

\section{WOMEN'S SOCIOECONOMIC DEVELOPMENT AND DEMOCRATIC RIGHTS IN THE CONSTITUTION}

There is considerable overlap between socioeconomic issues and those to which family relationships give rise. Questions such as whether or not women's domestic labor is valued, who is expected to bear the 
responsibility of child raising, whether or not women heads of family are protected, whether marriage gives husbands control over women's property, and rules on alimony and child support have the greatest impact on women's socioeconomic well-being. However, it is worth asking some additional questions.

Given that virtually in no country are women men's socioeconomic equals, the first obvious question is whether constitutions specifically address women's socioeconomic needs and whether the kinds of protections constitutions contain can backfire against women, especially within market economies. For instance, the Spanish Constitution prohibits sex discrimination in employment but some other constitutions, like the Colombian, the Costa Rican, and the Turkish explicitly provide for special protection for women workers, which, as the case law discussed in those countries' chapters shows, raises the question as to whether such clauses end up being freedom restricting or enhancing.

Moreover, it would seem that the horizontal application of fundamental rights would have a clear impact on women's socioeconomic well-being as, together with the family, the workplace, and educational institutions are two of the most frequent scenarios for discrimination against women in civil society. It is thus important to ask whether sex discrimination at work by private employers is a constitutional offence. In relation to that is discrimination on the basis of pregnancy, or sexual harassment, conceptualized as a constitutional offence?

Any feminist constitutional agenda that looks at results, and not just at intentions and formalities, should also address the constitutional status of socioeconomic rights in general, as opposed to first- and second-generation rights. Even when phrased in gender neutral terms, the rights to housing, education, health care, social security, and food, recognized by some constitutions, like the South African, have a gender impact, and will do so, as long as poverty has the face of a woman; for example, consider debates such as the one currently taking place in India, as to whether to make education a fundamental right by amending their Constitution are gendered.

Needless to say, women's political status is crucial to the overcoming of their social and economic subordination. Most women can vote and serve as elected political representatives, although few constitutions advert to these democratic rights. There are some exceptions. The United States Constitution is exceptional insofar as it guarantees both sexes equal voting rights; similarly the South African Constitution is unique in describing the composition of the National Assembly in terms of both genders. In addition, several countries have taken positive steps to ensure that women's democratic rights are recognized as possessing a participatory, as well as a formal legal, dimension. They have constitutional provisions and/or jurisprudence permitting or requiring quotas aimed at increasing women's political representation and participation in the public realm. In some countries, like in 
France, these have only come about after a highly disputed constitutional amendment process.

Constitutional law scholars should compare these participatory provisions and analyze the jurisprudence pertaining to them to identify their underlying conceptions. Although some may be perceived as temporary measures necessary to facilitate women's incorporation into the political and other public domains, others may be intended to redefine democratic representation more permanently according to a mirror representation approach. In addition, we need to examine the effect of context on adjudication. That is, have national courts reacted differently to quota, reserved seat, or parity legislation depending on whether it applies to political party candidacies, electoral lists, the judiciary, or public sector employment? Does it matter whether the quotas are specified, how they are derived, if they are mandatory, whether they also apply on grounds other than sex, or whether they contain explicit or implicit exonerations or sanctions?

Citizenship is also more broadly defined by the civic entitlements - both rights and duties - that the full members of any society can exercise. In terms of rights, we need to ask whether constitutions protect women's equal right to enjoy and to pass on membership status, given cases in which states have treated women unequally with respect to aboriginal, religious, citizenship, or residential status. In terms of duties, and related dignitary benefits, one of the major issues revolves around the constitutionality of exempting, excluding or limiting women's military, public, and jury service. Finally, no study of civic duties would be complete without addressing the issue of whether constitutions and constitutional doctrines treat women's reproductive capacity and unpaid domestic labour as social assets.

\section{CONSTITUTING WOMEN: THE GENDER OF CONSTITUTIONAL JURISPRUDENCE}

In what follows, the country contributors take very seriously the task of responding on a selective national basis to the questions raised by our feminist agenda. Not only do their answers enrich our understanding of the position of women in constitutional jurisprudence but also they fill a huge gap in the literature on comparative constitutionalism, the gender gap. Individually and collectively they challenge our acceptance of particular constitutional arrangements forcing us to question what may have seemed simply inevitable or obvious. "Broadening our perspective," as a feminist comparative constitutional law scholar recently argued, "may enable us to ask better questions and to better understand the answers that we find." ${ }^{5}$

I5 Kim Lane Schepple, "The Agendas of Comparative Constitutionalism" (2003) I3 (2) Law \& Courts: Newsletter of the Law and Courts Section of the American Political Science Association 5 at 22 online: Law and Courts Newsletter Web site <http://www.law.nyu.edu/lawcourts/pubs/ newsletter/springo3.pdf $>$ (date accessed: II/II/o3). 